\title{
NMES
}

New Middle Eastern Studies

ISSN: 2051-0861

Publication details, including guidelines for submissions:

https://journals.le.ac.uk/ojs1/index.php/nmes

\section{The Middle East - A Proposition Regarding the Method of Its Delimitation}

Author(s): Jan Byczkowski

To cite this article: Byczkowski, Jan (2021) "The Middle East - A Proposition Regarding the Method of Its Delimitation”, New Middle Eastern Studies 11 (2), pp. 16-41.

Online Publication Date: 2 March 2022

\section{Disclaimer and Copyright}

The NMES editors make every effort to ensure the accuracy of all the information contained in the journal. However, the Editors and the University of Leicester make no representations or warranties whatsoever as to the accuracy, completeness or suitability for any purpose of the content and disclaim all such representations and warranties whether express or implied to the maximum extent permitted by law. Any views expressed in this publication are the views of the authors and not the views of the Editors or the University of Leicester.

Copyright New Middle Eastern Studies, 2022. All rights reserved. No part of this publication may be reproduced, stored, transmitted or disseminated, in any form, or by any means, without prior written permission from New Middle Eastern Studies, to whom all requests to reproduce copyright material should be directed, in writing.

\section{Terms and Conditions}

This article may be used for research, teaching and private study purposes. Any substantial or systematic reproduction, re-distribution, re-selling, loan or sub-licensing, systematic supply or distribution in any form to anyone is expressly forbidden.

The publisher does not give any warranty express or implied or make any representation that the contents will be complete or accurate or up to date. The accuracy of any instructions, formulae and drug doses should be independently verified with primary sources. The publisher shall not be liable for any loss, actions, claims, proceedings, demand or costs or damages whatsoever or howsoever caused arising directly or indirectly in connection with or arising out of the use of this material. 


\title{
The Middle East - A Proposition Regarding the Method of Its Delimitation
}

\author{
Jan Byczkowski*
}

\begin{abstract}
While the term "Middle East" is in general use, its meaning remains flexible and dependent on one's imagination and agenda. The only systematic criticism of such a state of affairs seems to come from social scientists who discard the concept of the Middle East altogether, assuming it to be primarily driven by a (sub)conscious orientalism of the users. At the same time, no significant attempts have been done by social scientists who think that this term is of value in describing the political, social, cultural or economic reality. This article aims at filling this literature gap by proposing an experimental method of demarcating the Middle East via combining a number of historical, cultural, political, and economic factors. Hopefully, it will start a debate on what is the Middle East - which would not necessarily lead to discarding the concept altogether since, rather than leading to a practical solution, such a decision would result in a void with currently nothing to fill it. Before taking on this task, the first two parts of the article will be devoted to the history of "the Middle East" as a concept, as well as the problematic issue of region demarcation in general.
\end{abstract}

Keywords: Middle East; MENA; Political Geography; Regional Delimitation; Geopolitics; Middle Eastern Studies

\section{Introduction}

When mentioning "the Middle East", everybody seems to instinctively know where it is. Often, a sample number of countries are given instead of a precise description in the hope that the person will fill out the gap. However, after closer examination, apart from a few core members such as the Gulf States, Syria, and Iraq, the perplexity ensues. Various people and institutions add or remove regions and countries such as Maghreb, Turkey, Iran, and so on into and out of the mix. Therefore, for scientists, politicians, media, and lay people dealing with this region while not having it previously delimited poses a great risk of confusion. While the term itself is in general use, its meaning remains flexible and dependent on one's imagination and agenda. The only systematic criticism of such a state of affair seems to come from the scientists who discard the concept of the Middle East altogether, assuming it to be primarily driven by (sub)conscious orientalism of the users. At the same time, no significant attempts to defend it and provide a sound methodology of its delimitation have been undertaken by social scientists who think that this term is of value in describing the political,

\footnotetext{
*Jan Byczkowski, PhD Candidate in Political History and International Relations of the Middle East, Marmara University, Istanbul, Turkey. Email: jan.byczkowski90@gmail.com.
} 
social, cultural or economic reality. This article aims at filling this gap by proposing an experimental method of demarcating the Middle East combining a number of historical, cultural, political, and economic factors. Hopefully, it will start a debate on what is the Middle East which would not necessarily lead to discarding the concept altogether since, rather than leading to a practical solution, such a decision would result in a void with currently nothing to fill it. Before taking on this task, the first two parts of the article will be devoted to the history of "the Middle East" as a concept, as well as the problematic issue of region demarcation in general.

\section{The History of the Middle East as a Concept}

Before embarking on the history of the term "the Middle East", we can shortly examine the term "East" itself. It is often stipulated that it is a result of purely Eurocentric worldview and dates at least from the times of wars between Greeks and Persians, where it was described as the opposition of Europe and Asia (Said 1979: 56-58; Özalp 2011: 6-7). The concept was and to some extent is not merely a matter of geography but also a tool of differentiation between two "cultures" or "civilisations" and, apart from the "East", found their expression in another name in general use especially in the colonisation era - "the Orient", together with the way of thinking about it which is today known as "orientalism" thanks to the late Edward Said's book under the same title (Said 1979). As perceived by Europeans, the Orient was a land inhabited by inferior people characterised by a backward culture and very slow, if any, socioeconomic development. As Karen Culcasi argues in her article, the exact same stereotypes were transplanted into our understanding of what we now refer to as the Middle East (Culcasi 2010: 583-597).

As for the term "the Middle East", the first person to use it was not, as it is often supposed, Alfred T. Mahan, but general Thomas E. Gordon in the article entitled "The Problem of the Middle East" published in 1900 (Koppes 1976: 95-98). Mahan, however, was of great importance in the popularisation of the term due to his article entitled "The Persian Gulf and International Relations" which became an inspiration for Valentine Chirol to write his series of articles under the common title of "The Middle Eastern Question" (Mahan 1902: 39; Chirol 1903: 5). When and how the term gained popularity remains open for debates but it may be assumed that it became better known around the time of World War I (Koppes 1976; Culcasi 2010: 585). Still, the imaginary boundaries of the Middle East as seen by Gordon and Mahan differed greatly from what is commonly assumed to be the Middle East today. Gordon saw it as India and regions bordering it to the West, while Mahan, due to his interest in naval power, conceived it as defined by the waterway from Suez Canal to Singapore and lands lying next to it (Koppes 1976). This was caused mainly by the fact that there was already a term "Near East" in use for the lands of Northern Africa and Levant, while at the same time the concept of "Far East" was coined for China, Korea, Japan and lands to the south of them. Positioned against near and far East, the lands of Iran and India (and Arabian Peninsula in the case of Mahan) were assumed to be the Middle East. When it comes to the term "Near East" being replaced by the "Middle East" which remains in common use today, it happened gradually after the II World War (Culcasi 2010). 
Meanwhile, the imaginary boundaries of the Middle East were constantly changing. As it is shown on the maps provided by Carolina Center for the Study of the Middle East and Muslim Civilizations, throughout all the history of the term, it experienced a shift in meaning not only from country to country but also from institution to institution within one state (n.d.). In recent decades, independent institutions and state agencies started to employ geographically broader concepts under the name of the Middle East or some new names invented for this purpose. As an example, Middle East Studies Association and Middle East Institute continues to use the already established term for the purpose of their studies and publications but include in it the whole of the Maghreb including Mauretania, as well as Central Asian republics, Afghanistan, and Pakistan (ibid.). Similar territory was covered by "the Greater Middle East", a new term coined by the Bush administration in 2004 which has gained a significant influence as both the basis of American and NATO thinking about the region but also as a new source of critique of the subtle orientalism of American policies in the region which aimed at "democratisation", "democracy promotion", and "modernisation", often done by force (Ottaway and Carothers 2004; Wittes 2004). As for the European Union, it utilises three partially overlapping terms for this part of the world. "MENA" (Middle East and North Africa) includes seemingly all the countries from Iran to Morocco, while "Southern Neighbourhood" and "the Mediterranean" cover the countries on the shores of the Mediterranean Sea, including the southern and eastern one. ${ }^{1}$

To summarise, there is a tendency in recent years to expand the meaning of the Middle East or to coin a new name to incorporate one or more of the five following elements: the whole of Maghreb, Central Asian post-USSR republics, Caucasian post-USSR republics, Turkey, and Afghanistan paired with Pakistan. However, there is a lack of a clear method of determining the borders of the region (Culcasi 2010). After more than a hundred years of the term being in use, there is no scientific approach to the problem of its demarcation. Political scientists and geographers reiterate this deficiency but close to nothing was done to close this gap so far. In fact, there are whole books and articles dedicated to the issue of the Middle East's unsound foundations (Bonine, Amanat and Gasper 2012; Keddie 1973). To avoid this trap, some sources simply not mention what countries are included in the region and leave readers to guess. ${ }^{2}$ The other approach is to use one simple factor to delimitate the Middle East, be it the Arabic language or Islam. However, similarly to natural geography, such an approach is quite misleading. Choosing the Arabic language excludes Iran, one of the key players in the region. Similarly, focusing on Islam would allow us to include Indonesia, Bangladesh, Bosnia and Herzegovina, and Albania in the region, which also does not seem appropriate. Overall, the negligence regarding a more scientific determination of Middle Eastern borders leads to the situation where the very existence of the region is put in question since it seems to some like it is a product of pure imagination without any substance or justification.

Before proposing the method for determining which countries are the parts of the Middle East and which are not, it could be elaborated on why the Middle East should be delimitated at all. It could be argued that the concept is a simple continuation of Europecentred and orientalist term of "the Orient". However, is supposed orientalism the only rationale for the term's existence? I believe that there are other rationales to be taken into consideration. First of all, it is already an established term (even if without a certain 
geographical scope) which finds wide use in political science, politics, and departments of international institutions. Thousands of academic and non-academic books and articles were written on it, politicians from inside and outside the region are referring to it, and various institutions including the World Bank and IMF utilise the concept (or its variations such as MENA) for the purpose of effective work (The World Bank n.d.; International Monetary Fund n.d.). Getting rid of the term in the academic world will not necessarily result in a similar event among policymakers and the public. Moreover, even if the concept once was a rather empty shell without meaning other than superstitions, as the result of wide usage of it around the globe it started to live a life of its own. Finally, even many people from the region are using it on a daily basis, including regional media outlets (Al-Monitor n.d.; Ortadoğu Gazetesi n.d.).

\section{The Issues with Region Demarcation}

Determining a region is a complex task. According to Encyclopedia of Geography Term:

A region is a defined territory that indicates some common characteristic or feature, or that is structured or organized in such a way that it is distinguishable from the surrounding territory (Hanks 2011: 279).

The definition by Oxford Dictionary additionally adds the remark that regions have "not always fixed boundaries" (Oxford Living Dictionaries n.d.). Other sources in general repeat these traits. All of them, while simple, are far from sufficient and leave many questions up in the air. Acknowledging that there are thousands of features to choose from, which one can be assumed to be determining the existence of a particular region? What is the practicality of regions if they do not have always clear or fixed boundaries? Moreover, they give the impression that regions are a natural phenomenon, which is "discovered" rather than "created". However, this subject is a matter of great debate with some scientists claiming that a region is an "objective fact", while others deeming it an "intellectual concept", and others proposing a conciliatory conclusion that region can be both in the same time (Nir 1990: 5960 ). Perceiving regions as creations of one's mind or creations reflecting only to some degree the reality would be in line with the core concept of imagined communities by Bernard Anderson, which, while originally applied to nation-states, can be an explanation for the tendency to separate world into regions in line with the tendencies of Western powers and post-colonial states to demarcate, calculate, and rule. This subject is addressed in depth in his chapter entitled "Census. Map. Museum" (Anderson 2006: 163-178). Thus, social scientists from different fields may demarcate the borders of regions differently due to them utilising the factors of their particular interest. This approach results in four major types of regions possible to be determined by scientists:

1) Functional region

2) Single-feature region

3) Multiple-feature region

4) Total/systemic region (Nir 1990: 62). 
As the above names suggest, a functional region is a region determined for a specific purpose, serving a certain function, while remaining three types are based on features, ranging from 1 (single-feature region) to a total sum of all interactions and common characteristics (total/systemic region) (Ibid.: 62-66).

This short venture into the nature of regions as demarcated by academicians and politicians exposes the fact that all regions, even if they reflect the nature to some (bigger or lesser) extent, are the creations of imagination, or mental constructs. The closest to idealistic "reflecting the nature" are total regions but to demarcate them on an international level would necessitate enormous data processing. Moreover, even more generally accepted geographical categories are not purely reflecting the reality. Continents are also to some extent arbitrary concepts, with the special example of Europe and Asia which are arbitrarily separated by the Ural Mountains. It is often claimed that the distinction between the two is a direct continuation of the notion of West and East (later on Occident and Orient) adopted from ancient Greeks and preserved in our contemporary times (Lewis and Wigen 1997: 31-46; Parker 1960: 278-297; World Affairs 2002). Similarly, North and South America are thought to be separate continents despite the fact that they have been connected by Isthmus of Panama for the last couple million years (Lewis and Wigen 1997). Europe and Asia or North and South America as separate continents are, similarly to the Middle East, a result of a particular perception and do not find any justification in objective geographical findings.

Overall, calling the Middle East the artificial concept is merely uttering the accusation which is valid for most (if not all) of the regions and geographical or political concepts around the globe. Looking at the typology of regions, while we could not possibly dream of calling the Middle East as a total region, there is a chance to determine it as a multiple-feature region.

\section{Delimitating the Middle East: The Method}

The most important argument for the continued use and further clarification of the concept could be possible interrelations on various levels between the countries which form the Middle East and may be far more important than a simple East-West axis applied by $19^{\text {th }}$ and $20^{\text {th }}$ century Europeans and perceived the supposed "otherness" of the inhabitants. They again will possibly be called arbitrary for the author has chosen them among thousands of factors at hand but for a multiple-factor region, it is not an accusation but rather a fact-statement, for such a region may be determined using a variety of arbitrarily chosen factors. Still, even if we accept that it will be the product of our imagination and selection, the goal (even if never to be achieved) is to make it reflect, at least partially, the reality. Hence, in the method offered in this article, 7 factors belonging to 4 broad categories were chosen to determine whether a country belongs to the Middle East region or not. These broad categories are as follows:
1) History (1 factor)
2) Culture (2 factors)
3) Politics (3 factors)
4) Economy (1 factor) 
While all the above categories signify a particular interrelation, History and Culture consider the past and the influence of the past on contemporary countries and peoples, while Politics and Economy are more concerned with a recent history $\left(20^{\text {th }}\right.$ century and $21^{\text {st }}$ century $)$ as well as contemporary relations. As a result of this division and other factors involved, a visible disproportion exists between points granted to particular categories. History, while important, does not determine the present relations between states. Cultural factors also cannot be ignored but as we will see, especially one of them (religion - Islam) finds a limited use if applied as the only determinant in defining the region, for it became more widespread than the perceived borders of the Middle East. The economy is of lesser significance since many crucial states in the Middle East have a natural resources-based economy, which often leads to economic exchange being globally - rather than regionally-oriented. At the same time, there are no regional economic organisations as one could argue that OPEC is close to a regional economic cooperation organisation but it has member countries from around the globe such as Venezuela and Nigeria. Hence, export-import relations will be only a minor factor, for their structure does not imply that the strong inter-regional relations in other fields do not exist. As a result, it seems that political factors should play a major role in determining the borders of the Middle East. After all, the Middle East as a concept is most often applied in political science and especially in international relations. Institutional cooperation, perception and discourse, as well as political events, therefore, constitute the core of the method to be proposed.

In the current method, a 7-point scale was applied with 1 point for every main factor. Furthermore, 4 of the factors have sub-factors, each worth 0.5 points. In some cases, as it is to be seen, half-values ( 0.5 for 1 -point factors and 0.25 for 0.5 -point sub-factors) were applied where the answer is outside of the "true-false" binary choice. Subsequently, 4 points or more were accepted as the threshold for a state to be called a part of the Middle East - according to this method. States with scores such as 3.5-3.75 were assumed to be "contested", that is, being hard to classify at this point. Hopefully, continuing development of studies or a better choice of sources will allow for a definite determination of their status in the future.

There is one final remark to be made before presenting and applying the experimental method - it was conceived to delimitate the borders of the Middle East. Hence, it is concerned with determining the peripheral countries. However, to establish the peripheries, one ought to know the core. In this case, as the core of the Middle East were chosen the countries which appear in more than $2 / 3$ of various definitions of the region, namely Egypt, Syria, Lebanon, Iraq, Jordan, Iran, Israel ${ }^{3}$ and countries of the Arab Peninsula (Kuwait, Saudi Arabia, Bahrain, Qatar, UAE, Oman, Yemen). The comparison of the frequency of appearance of 45 countries across 18 definitions is included in Appendix 1. The core countries which were chosen this way, no matter the score gained by them in the method, will be accepted as parts of the Middle East due to their essential character. The factors taken into consideration are as follows, with categories in capital letters and factors as their sub-points:

\section{HISTORY (1 point)}

a) A significant piece of its territory belonged to the Ottoman or Qajar Empires (1 point): most of the historical "Orient" or "East" and what is now popularly considered to be the Middle East was covered historically by the Ottoman Empire and Qajar Empire. The 
Ottoman Empire ruled over the area stretching from modern Morocco to Iraq and from the Balkans and Caucasus to Yemen and Somali. Qajar Empire held parts of the Caucasus and modern Iran. Both were referred to as lands of the Orient and unlike today, were separated by a rather porous border allowing for trade, exchange of ideas and migration of nomadic tribes. Within the Ottoman Empire, the internal connections thrived also through trade and "pilgrimages" of officials and officers quite unlikely in European colonies, where the travels and relocations were limited to one's specific colony. ${ }^{4}$ Despite its multi-ethnicity and variety of languages and religions, there was a certain "Ottoman" identity, even if it was overshadowed by religious or ethnic identities. This identity is visible in the fact that many local movements were focused on the reform of the empire rather than independence and they were gaining irredentist character often with instigation from the European powers (Quataert 2005: 188-192). That and connections between state officials, in turn, provide for a certain common historical heritage. The heritage of the empire was and is stronger in the Muslim-majority countries, while Christian-majority countries share often a resentment towards it, which became an important part of their historical policies (Ibid.). In the same time, the "positive" heritage in Muslim countries which formed the Ottoman Empire is visible in their firstgeneration statesmen who often were graduates of Ottoman schools in Istanbul or provincial officials of the empire (Commins 1996: 19; Roded 1984: 247-282). Additionally, as yet another heritage of the empire, some states were formed from one or more of its vilayets and other administration entities, including Iraq (consisting of vilayets of Basra, Baghdad, and Mosul) and Egypt (hidivlik of Egypt).

As for the Qajar Empire, the mobility of students, officials and army officers existed on a much smaller level and the "Iranian" national identity was the product of the $20^{\text {th }}$ century. Nevertheless, similarly to the Ottoman Empire, in Qajar Iran the first schools of higher education such as Dar al-Fonun were founded in Tehran, hence forcing students to travel to the capital. Additionally, some of the local statesmen moved to the capital when they got appointed to higher offices or to the provinces when they fell from grace, although the shahs preferred to appoint their own sons to provincial capitals (Lorentz 2007: 81; Meredith 1971). There seem also to not exist any notion of a pronounced "Qajar" identity. Apart from their importance in the creation of common historical heritage of the region, the rivalry between Ottoman and Safavi (and later Qajar) Empires dressed by them as the Sunni-Shia conflict continues to influence the power dynamics in the Middle East, with main actors in ongoing sectarian strife being Saudi Arabia and Iran (Wehrey 2009: 11-43). Finally, by "significant piece of territory", author means a province or a large part of the country. As an example, fringes of today's Morocco were from time to time occupied by the Ottoman Empire but it does not mean a profound Ottoman influence in this country. Similarly, the Qajar Empire used to possess (or tried to conquer) the fringes of today's Turkmenistan and Afghanistan without leaving lasting influences there.

\section{CULTURE ( 2 points)}

a) The religion of the majority of the population is Islam (1 point) - it is true that using Islam as the only criterion of determining which countries form the Middle East leads to the inevitable inclusion of Indonesia and Bangladesh. However, instead of being the only one, it may serve as one of factors in determining the reach of the common culture of the region 
since it was the emergence and expansion of Islam during Muhammad's life as well as Rashidun and Umayyad Caliphates that changed the landscape of the region in both political and cultural meaning. Using Islam as an indicator, we are able to determine to what extent the first Islamic states had spread their influence for apart from a few examples (such as Georgia and Armenia) Christians and people of other faiths became over the centuries minorities in the conquered lands. The spread of Islam meant not only the introduction of a new religion but also of new law as well as a new universal language (Chase Robinson 2011: 13-14).

b) The Arabic Language (1 point) - introduced to the Middle East together with Islam in the conquest during the tenure of Muhammad, Rashidun, and Umayyads, Arabic provided a lingua franca for the Muslims and became the native language of the people inhabiting the vast stretch of land from North Africa to today's South-Western Iran (Ibid; Chism 2009). ${ }^{5}$ While the dialects may sometimes be of small intelligibility to people from other regions (as it is especially with the speakers of Moroccan and Yemeni dialects), all Arabic speakers know to some extent the Modern Standard Arabic, the language of Quran. Same is true for many Muslims whose native language is different from Arabic. Hence, the prevalence of Arabic, especially as an official language, may be an indicator of shared cultural space where people can communicate freely between each other - a factor which helped lay the foundations of the Middle East.

\section{POLITICS (3 points)}

1. Participation in regional political institutions (1 point) - While the Middle East does not have a purely regional institution comparable to CELAC or ASEAN, there are two organisations whose centre of gravity is located in the region. Participation in them should mean strengthened ties between the states and open new possibilities of cooperation and conflict resolution by peaceful means. These two are:

a) Organisation of Islamic Cooperation (OIC) (0.5 points) - OIC consists of Muslim countries and claims to be "the collective voice of the Muslim world" (Organisation of Islamic Cooperation n.d. b). While its members are many countries from outside the region (no matter the proposed boundaries) such as Indonesia, Malaysia, Bangladesh and many African countries, its General Secretariat and two of six subsidiary organisations are located in Saudi Arabia (Organisation of Islamic Cooperation n.d. a, c). Additionally, the birthplaces of Islam and its most sacred sites are all located in the region, including Mecca, Medina, and Karbala. Hence, participation in this organisation may show closer ties with the core countries and non-participation may indicate that the country's foreign policy is at least partially diverted towards other centres.

b) The League of Arab States (LAS, also known as Arab League - AL) (0.5 points) - LAS consists primarily of countries with majority Arab or Arabicspeaking population. However, Chad is not a member of the LAS despite its large minority of Arab as well as Arabic-speaking people (League of Arab States n.d.). In the same time, non-Arab states participate in the organisation - Somalia as a 
member and Eritrea as an observer (ibid.; AllAfrica 17.01.2003). Therefore, participation in the AL seems to signify not only a particular identity but also the will to participate in regional affairs.

c) Participation in major regional events (1 point) - there were many major political events and chains of events unfolding in the core of the Middle East. For the purpose of this method, two were chosen to signify the connection of the peripheral states with the core. These are:

i. Wars in the core ( 0.5 points) - states participating in the wars conducted in the core of the region did it as the result of regional cooperation and solidarity (for example the alliances of Arab states against Israel), concerned by threats of regional scale such as IS and other international terrorist organisations or out of perception that a particular conflict affects their interests.

ii. Arab Spring-related events (0.5 points) - Arab Spring which started in 2010 in Tunisia has shaken the region and led to government changes, civil unrest, and civil wars. The chain of events affected countries of similar culture and power relations, spreading from the Maghreb to the core of the Middle East and affecting the countries from Morocco to Iran and from Turkey to Yemen. ${ }^{6}$ It could be argued that the spread of the uprisings and protests had to do not only with the economy, corruption, and class divisions but also with feelings of kinship and similarity between the countries - that is why the spark of Tunisian protests found its way to so many countries.

d) Perception and discourse (1 point) - the perception and discourse are as important as other, more "material" evidence, for the ideas more often than not have the influence on the reality through the decisions of politicians, businesses, and other actors. There are two types of perception in question:

i. Self-perception ( 0.5 points) - if statesmen/public perceive their state as a Middle Eastern one, they may seek closer ties with other Middle Eastern states and create ties of solidarity and mutual help. Countries from the core were granted automatically full score in this aspect. Moreover, countries of Maghrib were also counted in due to their strong Arab identities. Other countries were considered individually.

ii. Perception by others ( 0.5 points) - how others perceive the country. If the majority consensus declares a country a Middle Eastern one, it is often presented in a block with other Middle Eastern countries and it receives similar treatment to other members. Moreover, international organisations and NGO's often have regional divisions and prepare regional reports and plans of actions, as well as initiatives. Hence, such a perception has a real influence on the action of national and international actors. In order to determine which country is perceived to be part of the Middle East, data from Appendix 1 was used. Countries with scores of 50\% and more were 
automatically granted full points in this category. Additionally, nowadays Maghrib countries are generally accepted to be the part of the Middle East or MENA, hence they were granted 0,25 points. Others (Mauritania and Djibouti) required some additional sources in order to gain half score.

\section{ECONOMY (1 point)}

a) The trade with the Middle East (1 point) - Due to the lack of regional economic organisations, the trade seems to be a sound, though limited, alternative to determine the economic cooperation and interrelations between Middle Eastern countries. Nevertheless, the limits of such an approach are visible in the dominant trade trends in the region. Many countries in the Middle East have exports dominated by hydrocarbon products (oil and gas) or raw materials which are shipped globally rather than locally. In the same time, their imports from the region are often overshadowed by China, USA, and Europe. Still, the structure of trade relations may be a minor indicator of interrelation within the region. The data regarding trade was acquired from UNCTAD database. The sub-categories utilised in the method are as follows:

i. Middle East-related exports (0.5 points) - if the average volume of exports to the ME in the years 2000-2016 was close to or exceeded 10\%, 0.25 point was given, while exports exceeding $15 \%$ were given 0.5 points.

ii. Middle East-related imports (0.5 points) - similarly, if the total volume of imports from the ME in the years 2000-2016 was close to or exceeded 10\%, 0.25 point was given, while exports exceeding $15 \%$ were given 0.5 points.

\section{The Results}

The aforementioned criteria were applied to 40 states, including 15 core states and 25 states of undetermined status surrounding the core. The results are presented in Appendix 2. As it is shown there, among core states only Israel did not receive 4 or more points and scored at 2.5. This is because of Israel's political and economic isolation from its direct neighbours due to the history of war and conflict with Arab states and Palestinian people. Apart from Israel, the lowest score among core states was scored by Iran, which gained 5 points due to the fact that it is not a majority Arab country, as well as United Arab Emirates $(5,25)$ which were never a part of either Ottoman or Qajar Empires.

The second category of states is peripheral states. To it, 7 states were qualified, scoring 4 or more points. These are: Sudan (7), Libya (6), Tunisia, Algeria $(5,75)$, Djibouti $(5,50)$ Morocco (4,75), and Turkey (4,25 points).

The third category is constituted by "contested" states - states who received approximately half of the possible score. If their past and present ties with the region were slightly stronger, we could assume them to be Middle Eastern states. As for now, concerning this particular method, they remain in a limbo of a kind, with their ties seemingly not sufficient to call them the members of Middle Eastern peripheries. There are two contested state - Mauritania (3,75 points) and Eritrea (3,25 points). As for Eritrea, it could be theorised that it would belong to the Middle East if not for its isolation for which it is sometimes called 
the "North Korea of Africa" (The Economist, 14.08.2018). Possibly it may establish stronger ties with the region if its political regime changes to a more liberal, open one. Then, since the method is relation-based, we could assume that Eritrea indeed became a part of the Middle East.

Finally, there is the fourth category, 16 "not qualified" states. These are the ones with scores lower than 3.5. The scores in this category were as follows: Somalia (3), Azerbaijan, Afghanistan, Chad (2.5), Pakistan, Tajikistan, and Mali (2,25), Turkmenistan (2), Kyrgyz Republic, Niger, Uzbekistan, Kazakhstan, Armenia (1.5), Ethiopia and Georgia (1), and South Sudan (0 points).

\section{Discussion}

The research shows that it is possible to design a methodically sound approach to determine the borders of the Middle East and deal with the stigma surrounding it. Hitherto studies, policy papers, and media coverage on the region were largely conducted by either choosing an arbitrary set of countries to be called "the Middle East" or by avoiding the question altogether, suggesting that the writer and the reader miraculously know "what is the Middle East". Such an approach presented, in author's opinion, a critical flaw, allowing for criticism from the positions of orientalism studies and post-colonial studies. However, is there a sound alternative? There are three approaches that come to mind:

1) Attaching the parts of the Middle East as we assume to know it to other nearby geopolitical or geographical regions: Iran to South and Central Asia, Turkey to Europe, Maghreb, Sudan, and Libya to Africa. Therefore, we are left with the core Middle East spanning from Syria and Iraq in the North to Yemen and Oman in the South and from Egypt in the West to Iraq in the East.

2) Creating new regions to describe the reality in this part of the world: Mesopotamia, Arab Peninsula, Maghreb, Levant, and Egypt + Eastern Libya (Cyrenaica)

3) Conducting particularistic studies on each country without searching for wider patterns or researching emerging interrelations as bilateral or trilateral at best.

All of these alternatives have their advantages and disadvantages. The first one allows for the exploration of rarely researched historical subjects such as trans-Saharan trade in case of Maghreb, the Iranian political and cultural influence spreading throughout the Central Asia, Afghanistan, Pakistan, all the way to India, or the Ottoman and Turkish influence in Caucasus and the Balkans. However, apart from the Afghan war and the Qaddafi's emphasis on African affairs and African Union, it does not offer a particularly useful framework to perceive the modern history of the region, especially after World War II. The second one would stumble upon similar difficulties as the concept of the Middle East - it is hard to perceive these regions in separation in the context of modern political and relation patterns. If Iran is not in Mesopotamia, what about its influence in Iraq or Syria? Is Syria a part of Levant or Mesopotamia? Is Turkey a part of Mesopotamia or Europe? While it is possible for a 
country to be a part of two or more geographical/geopolitical regions, in the Middle East separated into smaller entities, there would be a large number of countries which belong to two or more regions, deeming the separation unfeasible and more confusing than useful. Finally, the third approach offers an in-depth view of a particular country, but it would necessarily give predominance to the assumption that political, cultural or economic processes unravelling in it are endogenous. Particularistic approach may grant us a large volume of data to be used in more general, pattern-focused studies but would fail to grasp the processes such as the waves of Arab nationalism or the Arab Spring.

Instead, the method presented in this article present a move upstream - rather than dismantling and parcelling the old "Middle East", as it offers an explanation as to why does the concept has survived about 100 years of use in academic, political and lay circles and changes in terminology - from the "Near East" to "the Middle East" and, recently, to "MENA" and "Greater Middle East" preferred by some. The ongoing, both positive and negative interrelations and interactions between actors point to it being a part of geopolitical reality on the crossroads of historical, cultural, political, and economic interrelations. Assuming the Middle East to be a functional region leaves only one major flaw - the name itself. After all, this is one of the major counterarguments recalled by its critics - the name is indeed a European invention and is based on European perspective on geography. The name and its supposed meaning have become even more troubling if we realise that following the method, North African states as far West as Morocco and as far South as Sudan are, too, its members. Therefore, assuming the method to be working, the question remains of how we shall name this entity. For now, out of lack of other, better substitute (as mentioned before, the Arab World or the Islamicate will not do), for the time being it shall remain "the Middle East".

By utilising the method and proving that indeed such an entity, whatever its name, is a viable one based on measurable factors, it is possible to not only keep the categorisation already used in politics, academia, and media intact, but also to conduct further studies into dynamics of the region without the intense criticism and accusations of "orientalist" approach. Political, social, and economic science would no doubt benefit from these findings.

Finally, there is a short observation to be made regarding the methodology issues. The work on this method has unearthed spots which would require larger amounts of work in the future to provide quantitative, possibly objective data. Especially future wide-scale surveys on self-perception and perception by others could benefit greatly not only this work but also other studies focused on feelings of kinship and the prevalence of nationalism.

\section{Conclusion}

To summarise, 22 states have been determined using this method to constitute the Middle East as a multi-factor region for their scores are 4 out of 7 or higher. Of them, 15 are core states which generally find their places in various definitions of the region. Remaining 7 were previously included by some definitions whether as parts of the Middle East, the Middle East and North Africa or the Greater Middle East and according to the results of the method proposed in this article, were determined to have a sufficient bond with the core by both their 
past and their current cultural, political, and economic relations. Two countries (Mauritania and Eritrea) are in a somewhat ambiguous position and hopefully, the following research in the subject will help to establish their position in relation to the Middle East. The others, even if sometimes mentioned in definitions of the Middle East or bordering the core, were determined to not have sufficient historical, cultural, political, and economic ties to constitute the peripheries of the region.

Finally, it is important to reiterate that this is by no means a definite method of delimitation applicable to the Middle East. The primary goal of this article was to establish a first, hopefully at least moderately successful step towards a better understanding of what is the Middle East, a region which is the object of constant focus of world policymakers, media, and public alike yet until now it remained undefined, vague, dependent on preferences not bounded by any set of principles apart from basic utility (as it could be assumed for a number of economic and military bodies). Hopefully, it will provide a fresh start for a discussion on determining the Middle East using scientific methods. All comments and suggestions are more than welcome.

\section{Notes}

1. MENA is described rather vaguely as "North African and Middle Eastern countries". What the EU means by MENA may be partly understood through the list presented by European Council on Foreign Relations (Iran, Israel/Palestine, the Gulf, North Africa, Syria/Iraq/Lebanon), although it is an independent think tank. Southern Neighbourhood region includes 10 countries (Algeria, Egypt, Israel, Jordan, Lebanon, Libya, Morocco, Palestine, Syria and Tunisia). As for the Union for Mediterranean, it focuses on 15 countries on southern and eastern shores of the Mediterranean Sea including Algeria, Egypt, Israel, Jordan, Lebanon, Mauritania, Morocco, Palestine, Syria (suspended), Tunisia, and Turkey and a number of Balkan countries: European Union External Action. 2016. "Middle East and North Africa (MENA)". Accessed 10.03.2019. https://eeas.europa.eu/regions/middle-east-north-africa-mena/336/middle-east-and-northafrica-mena_en; European Council on Foreign Relations. n.d. "Middle East and North Africa". Accessed 10.03.2019. https://www.ecfr.eu/mena; European Commission. n.d. "Southern Neighbourhood". Accessed 10.03.2019. https://ec.europa.eu/neighbourhoodenlargement/neighbourhood/southern-neighbourhood_en; European Union External Action. 2016. Union for the Mediterranean (UfM). Accessed 10.03.2019. https://eeas.europa.eu/diplomatic-network/union-mediterranean-ufm/329/unionmediterranean-ufm_en.

2. As examples, W. G. East and J. R. V. Prescott mention "fourteen states" of the Middle East but do not provide a specific list, while A Companion to Political Geography does not give any information regarding supposed members of this region - W. Gordon East, J.R.V. Prescott, Our Fragmented World. An Introduction to Political Geography (London: 
Macmillan Press, 1975), 239-246; John Agnew, Katharyne Mitchell, Gerard Toal (ed.), A Companion to Political Geography (Oxford: Blackwell, 2003).

3. No matter the fact that some Middle Eastern states and Israel itself often do not perceive it as the part of the region, from the point of view of mere geography it is surrounded by core Middle Eastern states, not to mention that around half of the population in Israel proper and in occupied territories is of Middle Eastern origin (including not only Palestinians but also Sephardi and Mizrahi Jews). Moreover, Israel was an actor in a couple of most important conflicts in the region, including ongoing Israeli-Palestinian conflict but also 1948 Independence War, 1956 Suez Canal intervention, Six-Days-War, Yom Kippur War, Civil War in Lebanon and others.

4. The "pilgrimages" of officials and students within one territory were described as the focal point for the development of local nationalisms in colonies by B. Anderson. In Ottoman Empire, however, students and officials were not limited only to their own eyalet or provinces. Instead, students often learned in schools in Istanbul, while officials were freely moved from European to Asian provinces and back. Similarly, members of some powerful regional families served sometimes as high-ranking officials, including ministers, as it was with the son of sheikh Ubeydullah and the members of Baban Kurdish tribal chiefdom. The other noteworthy, though older, phenomenon was the existence until the 17th century of devshirme system which generated new Ottoman subjects with sometimes very limited sense of belonging to the regions they hailed from - B. Anderson. op.cit.., p. 56-58, 127-130; David Commins. 1996. "Abid, Ahmat Izzat al- (1851-1924)", “Abid, Muhammad Ali al- (1868-1939)", “Ahmad Pasha 'Al-Jazzar' (d. 1804)”, “Azm”, "Midhat Pasha (1822-1884)". In Historical Dictionary of Syria, David Commins, 18, 19, 24, 51-52, 155-156. Lanham: Scarecrow Press; Rohat Alakom. 1998. Eski İstanbul Kürtleri (1453-1925), Istanbul: Avesta, p. 71-73, 88-91; Karen Barkey. 2008. Empire of Difference. The Ottomans in Comparative Perspective, Cambridge: Cambridge University Press, p. 123-125; Gökhan Çetinsaya. 2006. Ottoman Administration of Iraq, 1890-1908, Oxon: Routledge, p. 49-58.

5. For elaborated list of dialects, geographical extension, and the usage of Arabic as the language of religion and lingua franca, please check: Kees Versteegh. 1997. The Arabic Language, New York: Columbia University Press, p. 148-240.

6. For more information on Arab Spring-related events in various countries you can check: Larbi Sadiki (ed.), Routledge Handbook of the Arab Spring, Routledge, London, 2015.

\section{References: Academic Sources}

[n.a.] (2002), "Defining the Borders of the New Europe," World Affairs vol. 164, No. 4, (Spring): 157-177.

Abadi, J. (2017), "Tunisia and Israel: relations under stress," Middle Eastern Studies, 53:4: 507-532. 
Abun-Nasr, J. M. (1971), A History of the Maghrib. Cambridge: Cambridge University Press.

Agnew, J., K. Mitchell, G. Toal (ed.) (2003), A Companion to Political Geography, Oxford: Blackwell.

Alakom, R. (1998), Eski İstanbul Kürtleri (1453-1925), Istanbul: Avesta.

Anderson, B. (2006), Imagined Communities. Reflections on the Origin and Spread of Nationalism. Revised Edition, London: Verso.

Avery, P., G. Hambly, C. Melville (ed.) (1991), The Cambridge History of Iran vol. 7. Cambridge: Cambridge University Press.

Barkey, K. (2008), Empire of Difference. The Ottomans in Comparative Perspective, Cambridge: Cambridge University Press, p. 123-125;

Bonine, Michael E., Abbas Amanat, Michael E. Gasper (ed.). Is There a Middle East? The Evolution of a Geopolitical Concept. Stanford: Stanford University Press, 2012.

Carley, P. (1995), Turkey's Role in the Middle East. A Conference Report, Washington D.C: United States Institute of Peace.

Chirol, Valentine. 1903. The Middle Eastern Question or some Political Problems of Indian Defence. London: John Murray. 624-631.

Chism, Ch. (2009), "Arabic in the Medieval World," PMLA vol. 124, No. 2 (March):

CIA (1975), Intelligence Report. The Arab-Israeli War: Overview and Analysis of the Conflict. https://www.cia.gov/library/readingroom/docs/1975-09-01A.pdf, accessed 14.03.2019.

Commins, D. (1996), "Abid, Ahmat Izzat al- (1851-1924)", "Abid, Muhammad Ali al(1868-1939)", “Ahmad Pasha 'Al-Jazzar' (d. 1804)", “Azm”, "Midhat Pasha (1822-1884)," in D. Commins, Historical Dictionary of Syria. Lanham: Scarecrow Press: 18, 19, 24, 51-52, 155-156.

Culcasi, K. (2010), "Geographical Record. Constructing and Naturalizing the Middle East," The Geographical Review 100 (4), (October): 583-597.

Çetinsaya, G. (2006), Ottoman Administration of Iraq, 1890-1908. Oxon: Routledge. Publishing.

Dunstan, S. (2003), The Yom Kippur War 1973 (2). The Sinai, Oxford: Osprey

East, W. G., J.R.V. Prescott (1975), Our Fragmented World. An Introduction to Political Geography, London: Macmillan Press. n.p.: Brill.

Edzard, L., R. de Jong (ed.) (2011), Encyclopedia of Arabic Language and Linguistics, 
Fasa'i, Hasan ibn Hasan (1972), History of Persia under Qajar Rule. Translated from the Persian of Hasan-e Fasa'i's Farsname-ye Naseri. New York: Columbia University Press.

Hanks, R. R. (2011), Encyclopedia of Geography Terms, Themes, and Concepts, Santa Barbara: ABC-Clio.

Harbom, L., E. Melander, P. Wallensteen (2008), "Dyadic Dimensions of Armed Conflict, 1946-2007', Journal of Peace Research 45(5) 2008: 697-710. https://ucdp.uu.se/downloads/\#d4, accessed 22.03.2019.

Jackson, P., L. Lockhart (ed.) (1986), The Cambridge History of Iran vol. 6. Cambridge: Cambridge University Press.

Keddie, N. R. (1973) "Is There a Middle East?". In: International Journal of Middle East Studies, Vol. 4, No. 3 (Jul.): 255-271.

Kılıç, O. (1997), 18. Yüzyılın İlk Yarısında Osmanlı Devleti'nin İdarî Taksimatı. Eyalet ve Sancak Tevcihatı. Elazığ: Ceren Maatbacılık.

Koppes, C. R. (1976), "Captain Mahan, General Gordon, and the Origins of the Term 'Middle East," Middle Eastern Studies, Vol. 12, No. 1 (January): 95-98.

Lewis, M. W., K. E. Wigen (1997), The Myth of Continents. A Critique of Metageography, Berkeley: University of California Press.

Lorentz, J. H. (2007), "Dar al-Fonun," in J. H. Lorentz, Historical Dictionary of Iran. Lanham: Scarecrow Press.

Maddy-Weitzman, B. (2015), “A Turning Point? The 'Arab Spring' and the Amazigh Movement," Ethnic and Racial Studies 38(14) (November): 1-17. DOI: 10.1080/01419870.2015.1061139.

Mahan, A. T. (1902), "The Persian Gulf and International Relations," in A.T. Mahan, Retrospects \& Prospect. Boston: Little, Brown, and Company: 209-254.

McGregor, A. (2011), "'The Notion of Spring Does Not Exist in the Arab World': Djibouti's President Ismail Guelleh Wards off the Arab Spring," Terrorism Monitor vol. IX, no. 47, 22.12.2011: 7-11. https://jamestown.org/program/the-notion-of-spring-does-not-existin-the-arab-world-djiboutis-president-ismail-guelleh-wards-off-the-arab-spring/.

Meredith, C. (1971), "Early Qajar Administration: An Analysis of Its Development and Functions," Iranian Studies vol. 4, No. 2/3 (Spring -Summer): 59-84.

Nir, D. (1990), Region as a Socio-Environmental System. An Introduction to a Systemic Regional Geography, Dordrecht: Kluwer Academic Publishers.

Ottaway, M., T. Carothers (2004), The Greater Middle East Initiative: Off to a False Start, Carnegie Endowment Policy Brief, https://carnegieendowment.org/files/Policybrief29.pdf, accessed on 24.10.2018. 
Özalp, O. N. (2011), "Where is the Middle East? The Definition and Classification Problem of the Middle East as a Regional Subsystem in International Relations," Turkish Journal of Politics vol. 2 No. 2 (Winter): 5-21.

Quataert, D. (2005), The Ottoman Empire 1700-1922, Cambridge: Cambridge University Press.

Parker, W. H. (1960), “Europe: How Far?”, The Geographical Journal vol. 126, No. 3 (September): 278-297.

Pearson, W. R., G. Tol, A. Stein, L. Hintz (2018), "Turkey's Emerging Role in the Middle East," Middle East Policy vol. XXV no. 2 (Summer). https://www.mepc.org/journal/turkeys-emerging-role-middle-east.

Pettersson, T., K. Eck (2018), “Organized violence, 1989-2017,” Journal of Peace Research 55(4). https://ucdp.uu.se/downloads/\#d4, accessed 22.03.2019.

Robinson, Ch. F. (2011), "Introduction," in Ch. F. Robinson (ed.), The New Cambridge History of Islam. Volume 1. The Formation of the Islamic World. Sixth to Eleventh Centuries. Cambridge: Cambridge University Press: 1-16.

Roded, Ruth Michal (1984), Tradition and Change in Syria during the Last Decades of Ottoman Rule: The Urban Elite of Damascus, Aleppo, Homs and Hama, 1876-1918, Ph.D. Thesis, University of Denver.

Sadiki, L. (ed.) (2015), Routledge Handbook of the Arab Spring, London: Routledge.

Sahillioğlu, H. (prep.) (2002), Topkapı Sarayı Arşivi H. 951-952 Tarihli ve E-12321 Numaralı Mühimme Defteri. Istanbul: IRCICA.

Said, E. (1979), Orientalism. London: Penguin Books.

Sarkees, M. R., F. Wayman (2010), Resort to War: 1816 - 2007, Washington DC: CQ Press. Accessed on 22.03.2019. http://www.correlatesofwar.org/data-sets/COW-war.

Simeone-Senelle, M.-C. (2011), "Djibouti/Eritrea," in L. Edzard, R. de Jong (ed.), Encyclopedia of Arabic Language and Linguistics. N.p.: Brill. http://dx.doi.org/10.1163/1570-6699_eall_EALL_SIM_0028.

Versteegh, K. (1997), The Arabic Language. New York: Columbia University Press.

Wehrey, F. et al (2009), Saudi-Iranian Relations since the Fall of Saddam, Rand Corporation, https://www.jstor.org/stable/pdf/10.7249/mg840srf.8.pdf, accessed 20.03.2019.

Wittes, T. C. (2004), The New U.S. Proposal for a Greater Middle East Initiative: An Evaluation, Brookings Report, https://www.brookings.edu/research/the-new-u-s-proposalfor-a-greater-middle-east-initiative-an-evaluation/, accessed on 24.10.2018. 


\section{References: Media Sources}

n.a. "East Africa: Eritrea Joins Arab League As Observer". AllAfrica. 17.01.2003. https://allafrica.com/stories/200301170205.html.

n.a. "Why Eritrea is called Africa's North Korea". The Economist, 14.08.2018. 20.03.2019. https://www.economist.com/the-economist-explains/2018/08/14/why-eritrea-iscalled-africas-north-korea.

Al Yafai, Faisal. "Mali coup shows Arab Spring instability bleeds over borders", The National, 3.04.2012. https://www.thenational.ae/mali-coup-shows-arab-spring-instabilitybleeds-over-borders-1.357500.

Arteh, Abdourahim. "Protests hit Djibouti, opposition leaders held", Reuters, 19.02.2011, $\quad$ https://www.reuters.com/article/ozatp-djibouti-protests-20110219idAFJOE71IOEN20110219.

Drennan, Justine. 'Who Has Contributed What in the Coalition Against the Islamic State?', Foreign Policy, 12.11.2014. https://foreignpolicy.com/2014/11/12/who-hascontributed-what-in-the-coalition-against-the-islamic-state/.

Ibish, Hussein. "Turkey is Changing the Middle East. The U.S. Doesn't Get It.". Bloomberg, 14.03.2019. https://www.bloomberg.com/opinion/articles/2019-03-14/turkey-ischanging-the-middle-east-the-u-s-doesn-t-get-it.

Kennard, Matt, Ismail Einashe. "For Somaliland and Djibouti, Will New Friends Bring Benefits?", Foreign Policy, 19.03.2019. https://foreignpolicy.com/2019/03/19/somalilandsomalia-horn-of-africa-djibouti-military-oil-uae-qatar-berbera-port/.

Rodenbeck, Max. 13.07.2013. "A Climate of Change”. The Economist, 17.03.2013. http://www.economist.com/sites/default/files/20130713_arab_spring.pdf.

Rohde, David. “'America's War for the Greater Middle East' by Andrew J. Bacevich”, The New York Times, 15.04.2016. https://www.nytimes.com/2016/04/17/books/review/americas-war-for-the-greater-middleeast-by-andrew-j-bacevich.html.

Zakaria, Fareed. 'The United States is stumbling into another decade of war', The Washington Post, 22.07.2017. https://www.washingtonpost.com/opinions/globalopinions/the-united-states-is-stumbling-into-another-decade-of-war/2017/06/22/7cd589f25796-11e7-a204-ad706461fa4f_story.html?utm_term=.5889822d1a49.

\section{References: Web Sources}

"Al-Monitor," Al-Monitor. https://www.al-monitor.com/pulse/home.html, accessed 10.03.2019. 22.03.2019.

"Djibouti," UNICEF. $\quad$ https://www.unicef.org/mena/topics/djibouti, accessed 
"General Secretariat," Organisation of Islamic Cooperation. https://www.oicoci.org/page/?p_id=38\&p_ref=14\&lan=en, accessed 20.03.2019.

"History," Organisation of Islamic Cooperation. https://www.oicoci.org/page/?p_id=52\&p_ref=26\&lan=en, accessed 20.03.2019.

"Interactive Data Table: World Muslim Population by Country," Pew Research Center. http://www.pewforum.org/chart/interactive-data-table-world-muslim-population-by-country/, accessed 21.03.2019.

"Mauritania," Crisis Group. https://www.crisisgroup.org/middle-east-northafrica/north-africa/mauritania, accessed 20.10.2019.

"Mauritania," Human Rights Watch. https://www.hrw.org/middle-east/nafrica/mauritania, accessed 20.10.2019.

"Mauritania," Middle East Eye. https://www.middleeasteye.net/content/154, accessed 20.10.2019.

"Mauritania," Middle East Monitor. https://www.middleeastmonitor.com/category/region/africa-2/mauritania/, $\quad$ accessed 20.10.2019.

"Member States," League of Arab States. http://www.lasportal.org/ar/aboutlas/Pages/CountryData.aspx, accessed 20.03.2019.

"Member States," Organisation of Islamic Cooperation. https://www.oicoci.org/states/?lan=en, accessed 22.03.2019.

"Middle East and North Africa," European Council on Foreign Relations. https://www.ecfr.eu/mena, accessed 10.03.2019.

"Middle East and North Africa (MENA)," European Union External Action. https://eeas.europa.eu/regions/middle-east-north-africa-mena/336/middle-east-and-northafrica-mena_en, accessed 10.03.2019.

"Middle East and North Africa," The World Bank http://www.worldbank.org/en/region/mena, accessed 5.03.2019.

"Middle East Center for Economics and Finance," International Monetary Fund. http://www.cef.imf.org/, accessed 5.03.2019.

“Oman," Country Studies. http://countrystudies.us/persian-gulf-states/102.htm, accessed 23.03.2019.

“Ortadoğu Gazetesi," Ortadoğu Gazetesi. http://www.ortadogugazetesi.net/, accessed 10.03.2019.

"Region," $\quad$ English. Oxford Living Dictionaries. https://en.oxforddictionaries.com/definition/region, accessed 15.03.2019. 
"Somalia," Middle East Monitor. https://www.middleeastmonitor.com/category/region/africa-2/somalia/, accessed 20.10.2019.

"Southern Neighbourhood," European Commission. https://ec.europa.eu/neighbourhood-enlargement/neighbourhood/southern-neighbourhood_en, accessed 10.03.2019.

"Subsidiary," Organisation of Islamic Cooperation. https://www.oicoci.org/page/?p_id=64\&p_ref=33\&lan=en, accessed 20.03.2019.

"UN Comtrade Database", United Nations. https://comtrade.un.org/data/, accessed 14.03.2019.

"United Nations Conference on Trade and Development," United Nations. https://unctadstat.unctad.org/EN/, accessed 22.03.2019.

"Union for the Mediterranean (UfM)," European Union External Action. https://eeas.europa.eu/diplomatic-network/union-mediterranean-ufm/329/unionmediterranean-ufm_en, accessed 10.03.2019.

"Where Is the Middle East?," Carolina Center for the Study of the Middle East and Muslim Civilizations. http://mideast.unc.edu/where/, accessed 09.03.2019.

"World Integrated Trade Solution," The World Bank. https://wits.worldbank.org/, accessed 21.03.2019.

\section{About the Author}

Jan Byczkowski is a PhD Candidate at Marmara University, Department of Political History and International Relations of the Middle East. His research interests include ethnic and religious groups and minorities in the region, decentralisation, federalism, anarchism, as well as political philosophy and theory in general. All comments and requests are welcome at: jan.byczkowski90@gmail.com. 
New Middle Eastern Studies, 11 (2)

Appendix 1 - Defining the Core of the Middle East using various definitions of the region

\begin{tabular}{|c|c|c|c|c|c|c|c|c|c|c|c|c|c|c|c|c|c|c|c|c|}
\hline \multirow[b]{2}{*}{ Country } & \multirow[b]{2}{*}{$\begin{array}{c}\text { Total } \\
\text { Score } \\
\text { out of } \\
18\end{array}$} & \multirow[b]{2}{*}{$\begin{array}{l}\text { Total } \\
\text { Score } \\
(\%)\end{array}$} & \multicolumn{18}{|c|}{ Middle East/Near East Definitions } \\
\hline & & & $\begin{array}{l}\text { MEI } \\
1947\end{array}$ & $\begin{array}{l}\text { MEI } \\
2005\end{array}$ & $\begin{array}{c}\text { MESA } \\
1970\end{array}$ & $\begin{array}{c}\text { MESA } \\
2000\end{array}$ & $\begin{array}{c}\text { Royal } \\
\text { Geogr. } \\
\text { Soc. } 1920\end{array}$ & $\begin{array}{c}\text { British } \\
\text { Official } \\
\text { Use } 1952\end{array}$ & $\begin{array}{c}\text { US } \\
\text { DoS } \\
\text { 1944 } \\
\text { (NE) }\end{array}$ & $\begin{array}{l}\text { US } \\
\text { DoS } \\
1948 \\
\text { (NE) }\end{array}$ & $\begin{array}{c}\text { US } \\
\text { DoS } \\
1992 \\
\text { (NE) }\end{array}$ & $\begin{array}{l}\text { UN Econ } \\
\text { Com for } \\
\text { ME } 1947\end{array}$ & $\begin{array}{l}\text { UN Econ } \\
\text { Com for } \\
\text { WA } 1977\end{array}$ & $\begin{array}{l}\text { ILO } \\
1947\end{array}$ & $\begin{array}{l}\text { ILO } \\
2005\end{array}$ & $\begin{array}{l}\text { FAO } \\
1948\end{array}$ & $\begin{array}{l}\text { FAO } \\
2005\end{array}$ & $\begin{array}{c}\text { IAEA } \\
1989 / \\
1990\end{array}$ & $\begin{array}{c}\text { WB } \\
1953\end{array}$ & $\begin{array}{c}\text { WB } \\
2005\end{array}$ \\
\hline Lebanon & 18 & $100 \%$ & 1 & 1 & 1 & 1 & 1 & 1 & 1 & 1 & 1 & 1 & 1 & 1 & 1 & 1 & 1 & 1 & 1 & 1 \\
\hline Syria & 18 & $100 \%$ & 1 & 1 & 1 & 1 & 1 & 1 & 1 & 1 & 1 & 1 & 1 & 1 & 1 & 1 & 1 & 1 & 1 & 1 \\
\hline Iraq & 18 & $100 \%$ & 1 & 1 & 1 & 1 & 1 & 1 & 1 & 1 & 1 & 1 & 1 & 1 & 1 & 1 & 1 & 1 & 1 & 1 \\
\hline Egypt & 17 & $94 \%$ & 1 & 1 & 1 & 1 & 0 & 1 & 1 & 1 & 1 & 1 & 1 & 1 & 1 & 1 & 1 & 1 & 1 & 1 \\
\hline Saudi Arabia & 17 & $94 \%$ & 1 & 1 & 1 & 1 & 1 & 1 & 1 & 1 & 1 & 1 & 1 & 1 & 1 & 1 & 1 & 1 & 0 & 1 \\
\hline Yemen & 17 & $94 \%$ & 1 & 1 & 1 & 1 & 1 & 1 & 1 & 1 & 1 & 1 & 1 & 1 & 1 & 1 & 1 & 1 & 0 & 1 \\
\hline Jordan & 16 & $89 \%$ & 1 & 1 & 1 & 1 & 1 & 1 & 1 & 1 & 1 & 0 & 1 & 0 & 1 & 1 & 1 & 1 & 1 & 1 \\
\hline Kuwait & 16 & $89 \%$ & 1 & 1 & 1 & 1 & 1 & 1 & 1 & 1 & 1 & 1 & 1 & 0 & 1 & 1 & 1 & 1 & 0 & 1 \\
\hline Bahrain & 16 & $89 \%$ & 1 & 1 & 1 & 1 & 1 & 1 & 1 & 1 & 1 & 1 & 1 & 0 & 1 & 1 & 1 & 1 & 0 & 1 \\
\hline Qatar & 16 & $89 \%$ & 1 & 1 & 1 & 1 & 1 & 1 & 1 & 1 & 1 & 1 & 1 & 0 & 1 & 1 & 1 & 1 & 0 & 1 \\
\hline UAE & 16 & $89 \%$ & 1 & 1 & 1 & 1 & 1 & 1 & 1 & 1 & 1 & 1 & 1 & 0 & 1 & 1 & 1 & 1 & 0 & 1 \\
\hline $\begin{array}{l}\text { Palestinian } \\
\text { Territories }\end{array}$ & 15 & $83 \%$ & 1 & 1 & 1 & 1 & 1 & 1 & 1 & 1 & 1 & 1 & 1 & 0 & 0 & 1 & 1 & 1 & 0 & 1 \\
\hline Oman & 15 & $83 \%$ & 1 & 1 & 1 & 1 & 1 & 1 & 1 & 1 & 1 & 0 & 1 & 0 & 1 & 1 & 1 & 1 & 0 & 1 \\
\hline Israel & 14 & $78 \%$ & 1 & 1 & 1 & 1 & 1 & 1 & 1 & 1 & 1 & 1 & 0 & 0 & 0 & 1 & 1 & 1 & 0 & 1 \\
\hline Iran & 13 & $72 \%$ & 1 & 1 & 1 & 1 & 1 & 1 & 0 & 0 & 1 & 1 & 0 & 1 & 0 & 1 & 1 & 1 & 0 & 1 \\
\hline Libya & 10 & $56 \%$ & 1 & 1 & 1 & 1 & 0 & 1 & 0 & 0 & 1 & 0 & 0 & 0 & 0 & 1 & 1 & 1 & 0 & 1 \\
\hline Turkey & 9 & $50 \%$ & 1 & 1 & 1 & 1 & 1 & 0 & 1 & 0 & 0 & 1 & 0 & 1 & 0 & 1 & 0 & 0 & 0 & 0 \\
\hline Sudan & 9 & $50 \%$ & 1 & 1 & 1 & 1 & 0 & 1 & 0 & 1 & 0 & 1 & 0 & 0 & 0 & 1 & 1 & 0 & 0 & 0 \\
\hline Aghanistan & 9 & $50 \%$ & 1 & 1 & 1 & 1 & 1 & 1 & 0 & 0 & 0 & 1 & 0 & 0 & 0 & 1 & 1 & 0 & 0 & 0 \\
\hline Djibouti & 8 & $44 \%$ & 1 & 1 & 1 & 1 & 0 & 1 & 0 & 0 & 0 & 1 & 0 & 0 & 0 & 1 & 1 & 0 & 0 & 0 \\
\hline Somalia & 7 & $39 \%$ & 1 & 0 & 1 & 1 & 0 & 1 & 0 & 0 & 0 & 1 & 0 & 0 & 0 & 1 & 1 & 0 & 0 & 0 \\
\hline Morocco & 6 & $33 \%$ & 1 & 1 & 1 & 1 & 0 & 0 & 0 & 0 & 1 & 0 & 0 & 0 & 0 & 0 & 0 & 0 & 0 & 1 \\
\hline Algeria & 6 & $33 \%$ & 1 & 1 & 1 & 1 & 0 & 0 & 0 & 0 & 1 & 0 & 0 & 0 & 0 & 0 & 0 & 0 & 0 & 1 \\
\hline Tunisia & 6 & $33 \%$ & 1 & 1 & 1 & 1 & 0 & 0 & 0 & 0 & 1 & 0 & 0 & 0 & 0 & 0 & 0 & 0 & 0 & 1 \\
\hline
\end{tabular}




\section{New Middle Eastern Studies, 11 (2)}

\begin{tabular}{|c|c|c|c|c|c|c|c|c|c|c|c|c|c|c|c|c|c|c|c|c|}
\hline Pakistan & 4 & $22 \%$ & 1 & 1 & 1 & 1 & 0 & 0 & 0 & 0 & 0 & 0 & 0 & 0 & 0 & 0 & 0 & 0 & 0 & 0 \\
\hline Tajikistan & 4 & $22 \%$ & 1 & 1 & 0 & 1 & 0 & 0 & 0 & 0 & 0 & 0 & 0 & 0 & 0 & 0 & 1 & 0 & 0 & 0 \\
\hline Kyrgyz Rep. & 4 & $22 \%$ & 1 & 1 & 0 & 1 & 0 & 0 & 0 & 0 & 0 & 0 & 0 & 0 & 0 & 0 & 1 & 0 & 0 & 0 \\
\hline Turkmenistan & 4 & $22 \%$ & 1 & 1 & 0 & 1 & 0 & 0 & 0 & 0 & 0 & 0 & 0 & 0 & 0 & 0 & 1 & 0 & 0 & 0 \\
\hline Cyprus & 4 & $22 \%$ & 1 & 0 & 0 & 0 & 0 & 1 & 1 & 0 & 0 & 0 & 0 & 0 & 0 & 1 & 0 & 0 & 0 & 0 \\
\hline Mauritania & 4 & $22 \%$ & 0 & 1 & 1 & 1 & 0 & 0 & 0 & 0 & 0 & 0 & 0 & 0 & 0 & 0 & 1 & 0 & 0 & 0 \\
\hline Western Sahara & 4 & $22 \%$ & 0 & 0 & 1 & 1 & 0 & 0 & 0 & 0 & 1 & 0 & 0 & 0 & 0 & 0 & 1 & 0 & 0 & 0 \\
\hline Eritrea & 3 & $17 \%$ & 1 & 0 & 0 & 0 & 0 & 1 & 0 & 0 & 0 & 0 & 0 & 0 & 0 & 1 & 0 & 0 & 0 & 0 \\
\hline Ethiopia & 3 & $17 \%$ & 1 & 0 & 0 & 0 & 0 & 1 & 0 & 0 & 0 & 0 & 0 & 0 & 0 & 1 & 0 & 0 & 0 & 0 \\
\hline Uzbekistan & 3 & $17 \%$ & 1 & 1 & 0 & 1 & 0 & 0 & 0 & 0 & 0 & 0 & 0 & 0 & 0 & 0 & 0 & 0 & 0 & 0 \\
\hline Kazakhstan & 3 & $17 \%$ & 1 & 1 & 0 & 1 & 0 & 0 & 0 & 0 & 0 & 0 & 0 & 0 & 0 & 0 & 0 & 0 & 0 & 0 \\
\hline Azerbaijan & 3 & $17 \%$ & 1 & 1 & 0 & 1 & 0 & 0 & 0 & 0 & 0 & 0 & 0 & 0 & 0 & 0 & 0 & 0 & 0 & 0 \\
\hline Armenia & 3 & $17 \%$ & 1 & 1 & 0 & 1 & 0 & 0 & 0 & 0 & 0 & 0 & 0 & 0 & 0 & 0 & 0 & 0 & 0 & 0 \\
\hline Georgia & 3 & $17 \%$ & 1 & 1 & 0 & 1 & 0 & 0 & 0 & 0 & 0 & 0 & 0 & 0 & 0 & 0 & 0 & 0 & 0 & 0 \\
\hline India & 2 & $11 \%$ & 1 & 0 & 0 & 1 & 0 & 0 & 0 & 0 & 0 & 0 & 0 & 0 & 0 & 0 & 0 & 0 & 0 & 0 \\
\hline Greece & 2 & $11 \%$ & 0 & 0 & 0 & 0 & 0 & 0 & 1 & 0 & 0 & 1 & 0 & 0 & 0 & 0 & 0 & 0 & 0 & 0 \\
\hline Bangladesh & 1 & $6 \%$ & 0 & 0 & 0 & 1 & 0 & 0 & 0 & 0 & 0 & 0 & 0 & 0 & 0 & 0 & 0 & 0 & 0 & 0 \\
\hline Mali & 0 & $0 \%$ & 0 & 0 & 0 & 0 & 0 & 0 & 0 & 0 & 0 & 0 & 0 & 0 & 0 & 0 & 0 & 0 & 0 & 0 \\
\hline Niger & 0 & $0 \%$ & 0 & 0 & 0 & 0 & 0 & 0 & 0 & 0 & 0 & 0 & 0 & 0 & 0 & 0 & 0 & 0 & 0 & 0 \\
\hline Chad & 0 & $0 \%$ & 0 & 0 & 0 & 0 & 0 & 0 & 0 & 0 & 0 & 0 & 0 & 0 & 0 & 0 & 0 & 0 & 0 & 0 \\
\hline South Sudan & 0 * & $0 \% *$ & 0 & 0 & 0 & 0 & 0 & 0 & 0 & 0 & 0 & 0 & 0 & 0 & 0 & 0 & 0 & 0 & 0 & 0 \\
\hline
\end{tabular}

* South Sudan has not yet existed as either a separate protectorate or state in the time those definitions were coined.

Source: Carolina Center for the Study of the Middle East and Muslim Civilizations. n.d. "Where Is the Middle East?". Accessed 09.03.2019. http://mideast.unc.edu/where/. Of definitions presented in the page some were not included due to a) being used by military/intelligence and, therefore, most probably not really interested in region per se but rather in geopolitical importance and geographical features (CIA, CENTCOM etc.) or b) using radically different terms such as "Arab States" (UNESCO) or "Eastern Mediterranean" (WHO). In the case of American Department of State maps, they continuously apply the name "Near East" despite the almost universal consensus among politicians and academia on using the Middle East term. Still, they were included, while the countries described there as the Middle East were excluded - the understanding of the Middle East in those documents in 1940s still resounded the first definitions proposed by Chirol and Gordon despite the new consensus. Abbreviations used: MEI - Middle East Institute; MESA - Middle Eastern Studies Association; US DoS - US Department of State; NE - "as Near East"; UN Econ Comm - United Nations Economic Commission; ILO - International Labor Organisation; FAO - Food and Agriculture Organisation; IAEA - International Atomic Energy Agency; WB - World Bank. 
New Middle Eastern Studies, 11 (2)

\section{Appendix 2 - The Method and Its Results}

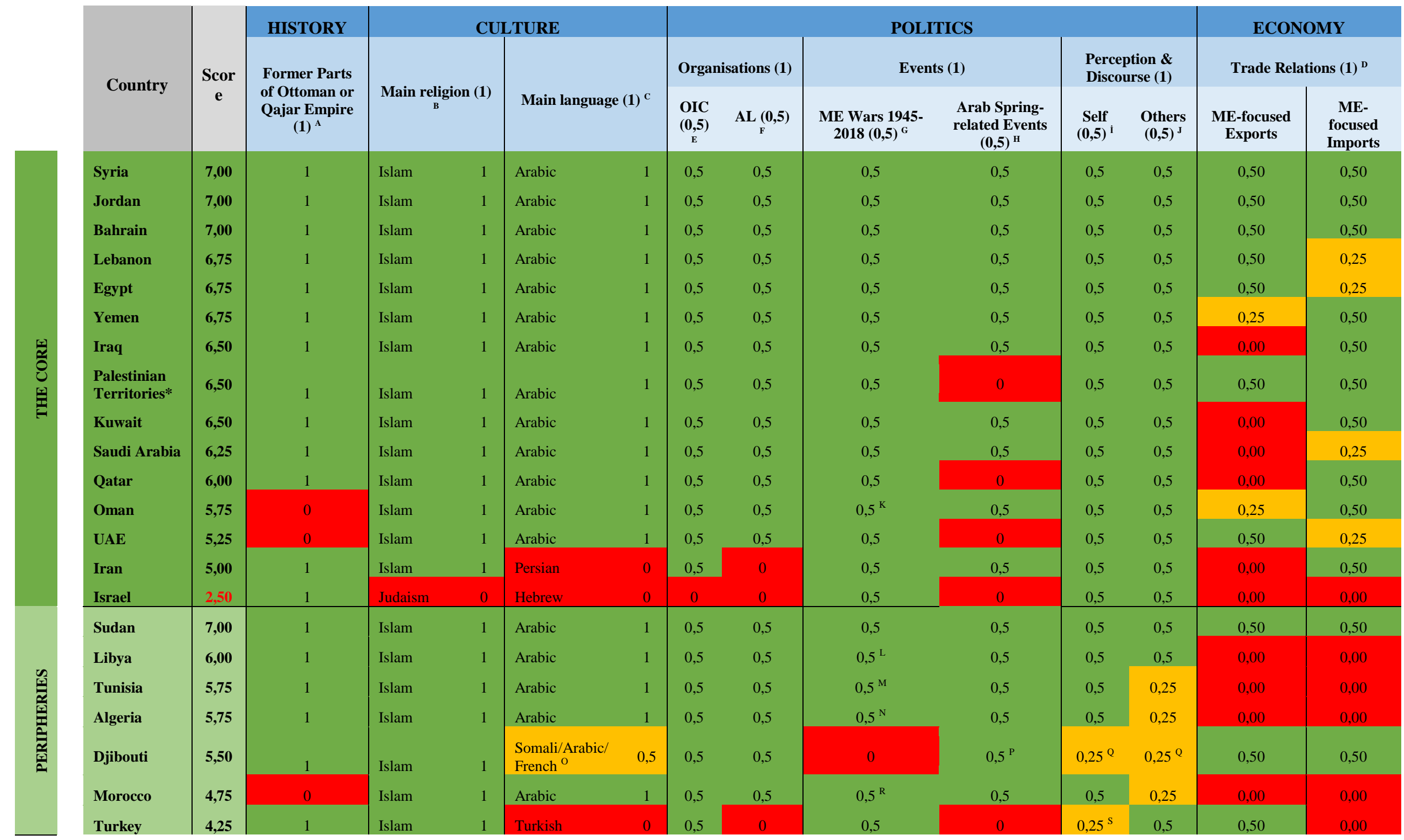


New Middle Eastern Studies, 11 (2)

\begin{tabular}{|c|c|c|c|c|c|c|c|c|c|c|c|c|c|c|c|}
\hline \multirow{2}{*}{ 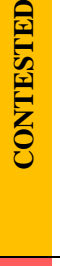 } & Mauritania & 3,75 & 0 & Islam & 1 & Arabic/French & 1 & 0,5 & 0,5 & 0 & 0,5 & 0 & $0,25^{\mathrm{T}}$ & 0,00 & 0,00 \\
\hline & Eritrea & 3,25 & 1 & Islam & 1 & $\begin{array}{l}\text { Tigrinya/Tigre/ } \\
\text { Arabic }^{\mathrm{U}}\end{array}$ & 0,5 & 0 & 0 & 0 & 0 & 0 & 0 & 0,25 & 0,50 \\
\hline \multirow{16}{*}{$\begin{array}{l}\overleftrightarrow{0} \\
0 \\
0 \\
z\end{array}$} & Somalia & 3,00 & 0 & Islam & 1 & Somali & 0 & 0,5 & 0,5 & 0 & 0 & 0 & 0 & 0,50 & 0,50 \\
\hline & Azerbaijan & 2,50 & 1 & Islam & 1 & Azeri/Russian & 0 & 0,5 & 0 & 0 & 0 & 0 & 0 & 0,00 & 0,00 \\
\hline & Aghanistan & 2,50 & 0 & Islam & 1 & Dari/Pashto & 0 & 0,5 & 0 & 0 & 0 & 0 & 0,5 & 0,00 & 0,50 \\
\hline & Chad & 2,50 & 0 & Islam & 1 & Arabic/French & 1 & 0,5 & 0 & 0 & 0 & 0 & 0 & 0,00 & 0,00 \\
\hline & Pakistan & 2,25 & 0 & Islam & 1 & Urdu & 0 & 0,5 & 0 & 0 & 0 & 0 & 0 & 0,25 & 0,50 \\
\hline & Tajikistan & 2,25 & 0 & Islam & 1 & Tajik/Russian & 0 & 0,5 & 0 & 0 & 0 & 0 & 0 & 0,50 & 0,25 \\
\hline & Mali & 2,25 & 0 & Islam & 1 & $\begin{array}{l}\text { French/Bambar } \\
\text { a }\end{array}$ & 0 & 0,5 & 0 & 0 & $0,25^{\mathrm{v}}$ & 0 & 0 & 0,00 & 0,50 \\
\hline & $\begin{array}{l}\text { Turkmenista } \\
\text { n }\end{array}$ & 2,00 & 0 & Islam & 1 & $\begin{array}{l}\text { Turkmen/ } \\
\text { Russian }\end{array}$ & 0 & 0,5 & 0 & 0 & 0 & 0 & 0 & 0,00 & 0,50 \\
\hline & Kyrgyzstan & 1,50 & 0 & Islam & 1 & $\begin{array}{l}\text { Kyrgyz/ } \\
\text { Russian }\end{array}$ & 0 & 0,5 & 0 & 0 & 0 & 0 & 0 & 0,00 & 0,00 \\
\hline & Niger & 1,50 & 0 & Islam & 1 & French/Hausa & 0 & 0,5 & 0 & 0 & 0 & 0 & 0 & 0,00 & 0,00 \\
\hline & Uzbekistan & 1,50 & 0 & Islam & 1 & Uzbek & 0 & 0,5 & 0 & 0 & 0 & 0 & 0 & 0,00 & 0,00 \\
\hline & Kazakhstan & 1,50 & 0 & Islam & 1 & $\begin{array}{l}\text { Kazakh/ } \\
\text { Russian }\end{array}$ & 0 & 0,5 & 0 & 0 & 0 & 0 & 0 & 0,00 & 0,00 \\
\hline & Armenia & 1,50 & 1 & Christianity & 0 & Armenian & 0 & 0 & 0 & 0 & 0 & 0 & 0 & 0,25 & 0,25 \\
\hline & Ethiopia & 1,00 & 0 & Christianity & 0 & Amharic & 0 & 0 & 0 & 0 & 0 & 0 & 0 & 0,50 & 0,50 \\
\hline & Georgia & 1,00 & 1 & Christianity & 0 & Georgian & 0 & 0 & 0 & 0 & 0 & 0 & 0 & 0,00 & 0,00 \\
\hline & South Sudan & 0,00 & 0 & Christianity & 0 & English & 0 & 0 & 0 & 0 & 0 & 0 & 0 & 0,00 & 0,00 \\
\hline
\end{tabular}

${ }^{\mathrm{A}}$ Some of the sources: Peter Jackson, Lawrence Lockhart (ed.), The Cambridge History of Iran vol. 6 (Cambridge: Cambridge University Press, 1986); P. Avery, G. Hambly, C. Melville (ed.), The Cambridge History of Iran vol. 7. (Cambridge: Cambridge University Press, 1991); Hasan ibn Hasan Fasa'i, History of Persia under Qajar Rule. Translated from the Persian of Hasan-e Fasa'i's Farsname-ye Naseri. (New York: Columbia University Press, 1972); Halil Sahillioğlu (prep.), Topkapı Sarayı Arşivi H. 951 - 
952 Tarihli ve E-12321 Numaralı Mühimme Defteri. (Istanbul: IRCICA, 2002); Orhan Kılıç, 18. Yüzyllın İlk Yarısinda Osmanlı Devleti'nin İdarî Taksimatı. Eyalet ve Sancak Tevcihatı. (Elazığ: Ceren Maatbacılık, 1997); Jamil M. Abun-Nasr, A History of the Maghrib. (Cambridge: Cambridge University Press, 1971).

B "Interactive Data Table: World Muslim Population by Country," Pew Research Center, accessed 21.03.2019. http://www.pewforum.org/chart/interactive-data-table-worldmuslim-population-by-country/.

${ }^{\mathrm{C}}$ Lutz Edzard, Rudolf de Jong (ed.), Encyclopedia of Arabic Language and Linguistics, (Leiden: Brill, 2011).

D "United Nations Conference on Trade and Development," United Nations, accessed 22.03.2019, https://unctadstat.unctad.org/EN/.

E "Member States," Organisation of Islamic Cooperation, accessed 22.03.2019, https://www.oic-oci.org/states/?lan=en.

F "Member States," League of Arab States, accessed 20.03.2019, http://www.lasportal.org/ar/aboutlas/Pages/CountryData.aspx.

${ }^{\mathrm{G}}$ The basic source were databases from Correlates of War (CoW) and Uppsala Conflict Data Program: Meredith Reid Sarkees, Frank Wayman, Resort to War: 1816 - 2007, (Washington DC: CQ Press 2010), accessed on 22.03.2019, http://www.correlatesofwar.org/data-sets/COW-war; Therése Pettersson. Kristine Eck, "Organized violence, 1989-2017", Journal of Peace Research 55(4) (2018), accessed 22.03.2019, https://ucdp.uu.se/downloads/\#d4.; Lotta Harbom, Erik Melander, Peter Wallensteen, "Dyadic Dimensions of Armed Conflict, 1946-2007”, Journal of Peace Research 45(5) 2008: p. 697-710, accessed 22.03.2019, https://ucdp.uu.se/downloads/\#d4. Additionally, some countries have participated in wars but were not mentioned in those databases - their cases have an endnote attached.

${ }^{\mathrm{H}}$ Larbi Sadiki (ed.), Routledge Handbook of the Arab Spring (London: Routledge, 2015); Max Rodenbeck, "A Climate of Change”, The Economist, 17.03.2013, http://www.economist.com/sites/default/files/20130713_arab_spring.pdf.

${ }^{\mathrm{I}}$ Countries from the core were granted automatically full score in this aspect. Moreover, countries of Maghrib were also counted in due to their strong Arab identities. ${ }^{\mathrm{J}}$ In order to determine which country is perceived to be the part of the Middle East, data from Appendix 1 was used. Countries with scores of 50\% and more were automatically granted full points in this category. Additionally, nowadays Maghrib countries are generally accepted to be the part of the Middle East or MENA, hence they were granted 0,25 points. Others (Mauritania and Djibouti) required some additional sources in order to gain half score.

${ }^{\mathrm{K}}$ Oman participated in the Persian Gulf War of 1991. Additionally, it participates in struggle against IS, although its role is undisclosed: "Oman," Country studies, accessed 23.03.2019, http://countrystudies.us/persian-gulf-states/102.htm; Justine Drennan, "Who Has Contributed What in the Coalition Against the Islamic State?," Foreign Policy,

12.11.2014, https://foreignpolicy.com/2014/11/12/who-has-contributed-what-in-the-coalition-against-the-islamic-state/.

${ }^{\mathrm{L}}$ Simon Dunstan, The Yom Kippur War 1973 (2). The Sinai, (Oxford: Osprey Publishing, 2003), 25.

M Ibidem; Jacob Abadi, “Tunisia and Israel: relations under stress," Middle Eastern Studies, 53:4 (2017): 507-532.

${ }^{\mathrm{N}}$ Ibidem.

${ }^{O}$ Marie-Claude Simeone-Senelle, "Djibouti/Eritrea," in Encyclopedia of Arabic Language and Linguistics, edited by Lutz Edzard, Rudolf de Jong. (Leiden: Brill, 2011), http://dx.doi.org/10.1163/1570-6699_eall_EALL_SIM_0028.

P Abdourahim Arteh. "Protests hit Djibouti, opposition leaders held," Reuters, 19.02.2011, https://www.reuters.com/article/ozatp-djibouti-protests-20110219-

idAFJOE71I0EN20110219; Andrew McGregor, “' 'The Notion of Spring Does Not Exist in the Arab World': Djibouti’s President Ismail Guelleh Wards off the Arab Spring”, Terrorism Monitor vol. IX, no. 47 (2011): 7-11. https://jamestown.org/program/the-notion-of-spring-does-not-exist-in-the-arab-world-djiboutis-president-ismail-guellehwards-off-the-arab-spring/.

${ }^{Q}$ The position of Djibouti in the eyes of politicians, organisations and media remains ambiguous, with some of them accepting Djibouti as the part of MENA (f.e. UNICEF, World Bank), while others treating it as a country neighbouring the region rather than a part of it (Foreign Policy): "Djibouti," UNICEF, accessed 22.03.2019,

https://www.unicef.org/mena/topics/djibouti; "Middle East and North Africa," The World Bank, accessed 5.03.2019, http://www.worldbank.org/en/region/mena; Matt Kennard, Ismail Einashe. “For Somaliland and Djibouti, Will New Friends Bring Benefits?”, Foreign Policy, 19.03.2019, https://foreignpolicy.com/2019/03/19/somalilandsomalia-horn-of-africa-djibouti-military-oil-uae-qatar-berbera-port/.

${ }^{\mathrm{R}}$ Moroccan troops participated in the 1973 Arab-Israeli war: CIA. 1975. Intelligence Report. The Arab-Israeli War: Overview and Analysis of the Conflict, accessed 14.03.2019. https://www.cia.gov/library/readingroom/docs/1975-09-01A.pdf; S. Dunstan, The Yom Kippur... 


\footnotetext{
S Turkey's position between Europe and the Middle East has also led to a fair amount of discussion regarding its identity. Internally, society is divided between kemalists who support the idea of Turkey being part of Europe and more conservative part of society associated usually (but not always) with the AKP party ruling since 2002 which increasingly underlines that Turkey is a Middle Eastern country - As for the international scene, there is a growing consensus on it being a 'bridge between Europe and Asia' and in the same time a major player in the Middle East - W. Robert Pearson, Gonul Tol, Aaron Stein, Lisel Hintz, "Turkey's Emerging Role in the Middle East", Middle East Policy, vol. XXV no. 2 (Summer 2018), https://www.mepc.org/journal/turkeys-emerging-role-middle-east; Hussein Ibish. "Turkey is Changing the Middle East. The U.S. Doesn't Get It.”. Bloomberg, 14.03.2019, https://www.bloomberg.com/opinion/articles/2019-03-14/turkey-is-changing-the-middle-east-the-u-s-doesn-t-get-it; Particia Carley, Turkey's Role in the Middle East. A Conference Report (Washington D.C: United States Institute of Peace, 1995).

${ }^{\mathrm{T}}$ While older definitions did not include Mauritania within the Middle East, nowadays, the trend is changing and it is more often mentioned as the part of MENA (Middle East and North Africa), which became the new popular term in use (look: Appendix 1). Moreover. some organisation and media include Mauritania in their 'MENA' subdivisions/categories, however, without presenting any reasoning as for why they did so, including: "Mauritania," Human Rights Watch, accessed 21.10.2019, https://www.hrw.org/middle-east/n-africa/mauritania; "Mauritania," Crisis Group, accessed 20.10.2019, https://www.crisisgroup.org/middle-east-north-africa/northafrica/mauritania; "Mauritania," Middle East Monitor, accessed 20.10.2019, https://www.middleeastmonitor.com/category/region/africa-2/mauritania/; “Mauritania," Middle East Eye, accessed 20.10.2019, https://www.middleeasteye.net/content/154.

U M.-C. Simeone-Senelle, "Djibouti/Eritrea"...

$\mathrm{v}$ The ongoing violence in Mali, while not a result of popular protests like in other countries, could be attributed to Arab Spring in two different ways: either as the result of Tuareg mercenaries losing their jobs in Libya and simply coming home and disturbing the political balance or as a movement which took inspiration from Arab Spring event in other countries: Bruce Maddy-Weitzman, “A Turning Point? The 'Arab Spring' and the Amazigh Movement”. Ethnic and Racial Studies 38(14) (November 2015): 1-17; Faisal Al Yafai. "Mali coup shows Arab Spring instability bleeds over borders", The National, 3.04.2012, https://www.thenational.ae/mali-coup-shows-arab-springinstability-bleeds-over-borders-1.357500.
} 